\title{
Evaluation of oenological potential on clonal selections of cv. Cabernet Sauvignon from Chile
}

\author{
C. Ceppi de Lecco, Ph. Pszczólkowski, J. Pérez-Harvey, S. Najera, and C. Tastets \\ PUC Pontificia Universidad Católica de Chile, Departamento de Fruticultura y Enología, Chile
}

\begin{abstract}
Cabernet Sauvignon, established in Nancagua VI Region, Chile $\left(34.39^{\circ} \mathrm{S} 71.17^{\circ} \mathrm{W}\right)$. The genetic identity of the vines was confirmed by ampelography and microsatellite markers (SSR). Evaluations in the 2012-2013 season include: performance, analytical and sensorial parameters on the wines made by microvinification. The results were statistically analyzed with the Statgraphics Plus program and multiple comparison test of Tukey at $95 \%$ confidence level. Sensorially, the wines were evaluated by a panel of 12 experts. The results were likewise analyzed by testing principal components (PCA) with covariance matrix without rotation. In the season studied the selection 108 highlighted with a high yield ( $\mathrm{kg} / \mathrm{plant})$, in the composition of the wine selections generally highlighted for contents of total polyphenols and anthocyanins over average. The results show typical sensory characteristics of wines from that grape variety, and it was possible to group the selections by their attributes (PCA) with cherry red wines at different intensities, but without significant differences, with fruity and vegetal aromas, interesting complex flavors and with structured tannins.
\end{abstract}

\section{Introduction}

Chile has positioned itself in the world as a producer of high-quality red wines.

It is currently standing at fourth place in the wineexporting countries. Standing out among others with wines from cv. Cabernet Sauvignon, the excellence and authenticity of their wines [1].

In Chile, the cultivar Cabernet -Sauvignon with an area of 42,195 $\mathrm{Ha}$ of a national total of $130361 \mathrm{Ha}$ [2], ranks first in area of red cultivars [3].

Since the country has a high diversity of genetic material from vines originated with the importation of century XIX noble strains, before the destruction of European vineyards by phylloxera, which is why is it possible to select clones of good quality wine.

The objective of this study was to evaluate the similarities and differences of wine making potential of 13 clonal selections of Chilean cv. Cabernet Sauvignon.

\section{Materials and methods}

During the agricultural season 1999-2000 at the Catholic University of Chile, a search for clones of different varieties began in the central-south area of the country [4].

The genetic identity of the vines was confirmed by ampelography and microsatellite markers (SSR).

This Clonal Selection Program, currently located in the commune of Nancagua, Region VI Libertador Bernardo O'Higgins $\left(34.39^{\circ} \mathrm{S} 71.17^{\circ} \mathrm{W}\right)$, has 13 selections of $\mathrm{cv}$ Cabernet Sauvignon, which were established in the 20082009 season [5]. This cultivation zone is characterized by a semiarid Mediterranean climate, with hot summers and cold winters, high thermal amplitudes and prolonged dry season of 7 to 8 months [2].

The trial was designed in randomized complete block with 3 replications, using as experimental unit a group of 12 plants. Clonal selections were established rootstock on trellises, NS orientation.

In this study are presented the results of evaluations of productive, analytical and sensorial parameters from wines of the 2012-2013 season.

The grapes of the 13 selections were harvested at approximately $25^{\circ}$ Brix and the obtaining of the wines was performed by microvinification, in which the maceration is mild compared to industrial.

The results were statistically analyzed with the Statgraphics Plus program and multiple comparison test of Tukey at $95 \%$ confidence level. Sensorially the wines were evaluated by a panel of 12 experts. The results were likewise analyzed by testing principal components (PCA) with covariance matrix without rotation.

The aspects evaluated were: visual characters (evolution and intensity), olfactory characters (fresh fruit, dried fruit, vegetable, dry vegetable), gustatory characters (alcohol, acidity, astringency intensity, dryness and body) and overall quality; which were evaluated on a scale of 1 (lowest perception) to 9 (highest perception).

\subsection{Results and discussion}

\subsection{Yield components}

Looking at the results, berry weight, cluster weight and yield (kg/plant) (Table 1) shows that the cluster in the selection 108 is $48.4 \%$ heavier than the average, however

This is an Open Access article distributed under the terms of the Creative Commons Attribution License 4.0, which permits unrestricted use, distribution, and reproduction in any medium, provided the original work is properly cited. 
Table 1. Yield componets: Berry wt (g), cluster wt (g), and yield (kg-vine) of selections of cv. Cabernet-Sauvignon (season 20122013) Nancagua, VI región. Chile.

\begin{tabular}{cccc}
\hline & $\begin{array}{c}\text { Peso baya } \\
(\mathbf{g})\end{array}$ & $\begin{array}{c}\text { Peso racimo } \\
(\mathbf{g})\end{array}$ & $\begin{array}{c}\text { Rdto./planta } \\
(\mathbf{k g})\end{array}$ \\
\hline $\mathbf{1 0 2}$ & $1.50 \mathrm{a}$ & $122.5 \mathrm{a}$ & $2.27 \mathrm{a}$ \\
$\mathbf{1 0 4}$ & $1.50 \mathrm{a}$ & $147.4 \mathrm{a}$ & $2.40 \mathrm{a}$ \\
$\mathbf{1 0 6}$ & $1.53 \mathrm{a}$ & $135.4 \mathrm{a}$ & $2.37 \mathrm{a}$ \\
$\mathbf{1 0 8}$ & $1.60 \mathrm{a}$ & $205.0 \mathrm{~b}$ & $4.60 \mathrm{~b}$ \\
$\mathbf{1 1 2}$ & $1.50 \mathrm{a}$ & $127.5 \mathrm{a}$ & $2.43 \mathrm{a}$ \\
$\mathbf{2 0 1}$ & $1.53 \mathrm{a}$ & $134.2 \mathrm{a}$ & $2.43 \mathrm{a}$ \\
$\mathbf{2 0 2}$ & $1.53 \mathrm{a}$ & $126.0 \mathrm{a}$ & $2.43 \mathrm{a}$ \\
$\mathbf{2 0 6}$ & $1.53 \mathrm{a}$ & $130.2 \mathrm{a}$ & $2.10 \mathrm{a}$ \\
$\mathbf{2 0 8}$ & $1.40 \mathrm{a}$ & $122.7 \mathrm{a}$ & $2.03 \mathrm{a}$ \\
$\mathbf{3 0 1}$ & $1.33 \mathrm{a}$ & $129.0 \mathrm{a}$ & $2.77 \mathrm{a}$ \\
$\mathbf{3 0 8}$ & $1.53 \mathrm{a}$ & $126.5 \mathrm{a}$ & $2.80 \mathrm{a}$ \\
$\mathbf{4 0 1}$ & $1.47 \mathrm{a}$ & $149.0 \mathrm{a}$ & $2.43 \mathrm{a}$ \\
$\mathbf{4 0 8}$ & $1.50 \mathrm{a}$ & $139.3 \mathrm{a}$ & $2.93 \mathrm{a}$ \\
\hline Mean & 1.50 & 138.1 & 2.62 \\
\hline Values followed by different letters are different according to the
\end{tabular}

Tukey procedure of significant difference, $\mathrm{P}<0.05$.

Table 2. Anthocyanins, total polyphenols ( ITP), color intensity (IC), selections of cv. Cabernet-Sauvignon (season 2012-2013) Nancagua, VI región. Chile.

\begin{tabular}{cccc}
\hline & $\begin{array}{c}\text { Antocianas } \\
(\mathbf{m g} / \mathrm{L})\end{array}$ & $\begin{array}{c}\text { Polifenoles } \\
\text { totales }\end{array}$ & $\begin{array}{c}\text { Intensidad } \\
\text { colorante }\end{array}$ \\
\hline $\mathbf{1 0 2}$ & $372.7 \mathrm{a}$ & $45.6 \mathrm{a}$ & $8.03 \mathrm{a}$ \\
$\mathbf{1 0 4}$ & $409.0 \mathrm{a}$ & $43.0 \mathrm{a}$ & $6.61 \mathrm{a}$ \\
$\mathbf{1 0 6}$ & $347.7 \mathrm{a}$ & $46.0 \mathrm{a}$ & $7.37 \mathrm{a}$ \\
$\mathbf{1 0 8}$ & $378.7 \mathrm{a}$ & $43.0 \mathrm{a}$ & $7.32 \mathrm{a}$ \\
$\mathbf{1 1 2}$ & $363.3 \mathrm{a}$ & $51.1 \mathrm{a}$ & $8.51 \mathrm{a}$ \\
$\mathbf{2 0 1}$ & $354.3 \mathrm{a}$ & $62.6 \mathrm{~b}$ & $8.24 \mathrm{a}$ \\
$\mathbf{2 0 2}$ & $377.7 \mathrm{a}$ & $50.3 \mathrm{a}$ & $6.90 \mathrm{a}$ \\
$\mathbf{2 0 6}$ & $368.0 \mathrm{a}$ & $47.6 \mathrm{a}$ & $6.54 \mathrm{a}$ \\
$\mathbf{2 0 8}$ & $337.3 \mathrm{a}$ & $50.8 \mathrm{a}$ & $7.41 \mathrm{a}$ \\
$\mathbf{3 0 1}$ & $358.3 \mathrm{a}$ & $42.7 \mathrm{a}$ & $6.61 \mathrm{a}$ \\
$\mathbf{3 0 8}$ & $350.3 \mathrm{a}$ & $50.0 \mathrm{a}$ & $7.51 \mathrm{a}$ \\
$\mathbf{4 0 1}$ & $349.0 \mathrm{a}$ & $47.3 \mathrm{a}$ & $7.16 \mathrm{a}$ \\
$\mathbf{4 0 8}$ & $292.7 \mathrm{a}$ & $44.1 \mathrm{a}$ & $5.47 \mathrm{a}$ \\
\hline Mean & 358.4 & 48.0 & 7.21 \\
\hline
\end{tabular}

Values followed by different letters are different according to the Tukey procedure of significant difference, $\mathrm{P}<0.05$.

the selection 102 presented the lowest weight in their clusters $(11.3 \%$ less) compared to the average. Presented significant differences in performance 108 is a $50 \%$ higher than average, and 208 showed a $22.5 \%$ lower yield.

\subsection{Wine analysis}

The average concentration of anthocyanins was $358.4 \mathrm{mg} / \mathrm{L}$, with the lowest value of $292.7 \mathrm{mg} / \mathrm{L}$ for selection 408 , and the greatest of $409.0 \mathrm{mg} / \mathrm{L}$ for selection 104 , with no significant differences between selections. (Table 2).

The values of total polyphenol index (IPT) average was 48.0, 42.7 being the lowest in the selection 301 and the largest 62.6 in the selection 201, there was significant difference.
Table 3. Titratable acidity, $\mathrm{pH}$, alcohol vol \% of the wines of the 13 clonal selections of cv. Cabernet-Sauvignon (season 20122013), Nancagua, VI región. Chile.

\begin{tabular}{cccc}
\hline & $\begin{array}{c}\text { Acidez } \\
\text { titulable } \\
\left(\mathbf{g} / \mathbf{L ~ H}_{\mathbf{2}} \mathbf{S O}_{\mathbf{4}}\right)\end{array}$ & pH vino & $\begin{array}{c}\text { Grado } \\
\text { alcohólico }\end{array}$ \\
\hline $\mathbf{1 0 2}$ & $4.00 \mathrm{a}$ & $3.82 \mathrm{abc}$ & $14.6 \mathrm{a}$ \\
$\mathbf{1 0 4}$ & $3.22 \mathrm{a}$ & $4.05 \mathrm{c}$ & $13.5 \mathrm{a}$ \\
$\mathbf{1 0 6}$ & $3.64 \mathrm{a}$ & $4.05 \mathrm{c}$ & $14.3 \mathrm{a}$ \\
$\mathbf{1 0 8}$ & $3.47 \mathrm{a}$ & $4.02 \mathrm{c}$ & $13.6 \mathrm{a}$ \\
$\mathbf{1 1 2}$ & $4.12 \mathrm{a}$ & $3.61 \mathrm{a}$ & $14.6 \mathrm{a}$ \\
$\mathbf{2 0 1}$ & $3.67 \mathrm{a}$ & $3.92 \mathrm{abc}$ & $14.4 \mathrm{a}$ \\
$\mathbf{2 0 2}$ & $3.20 \mathrm{a}$ & $4.03 \mathrm{c}$ & $13.8 \mathrm{a}$ \\
$\mathbf{2 0 6}$ & $3.29 \mathrm{a}$ & $3.91 \mathrm{abc}$ & $13.6 \mathrm{a}$ \\
$\mathbf{2 0 8}$ & $4.00 \mathrm{a}$ & $3.64 \mathrm{ab}$ & $14.4 \mathrm{a}$ \\
$\mathbf{3 0 1}$ & $3.58 \mathrm{a}$ & $3.78 \mathrm{abc}$ & $14.0 \mathrm{a}$ \\
$\mathbf{3 0 8}$ & $3.43 \mathrm{a}$ & $3.98 \mathrm{c}$ & $14.1 \mathrm{a}$ \\
$\mathbf{4 0 1}$ & $3.41 \mathrm{a}$ & $3.99 \mathrm{c}$ & $14.1 \mathrm{a}$ \\
$\mathbf{4 0 8}$ & $3.32 \mathrm{a}$ & $3.95 \mathrm{bc}$ & $13.9 \mathrm{a}$ \\
\hline Mean & 3.57 & 3.90 & 14.1 \\
\hline Values followed by different letters are different according to the \\
Tukey procedure of significant difference, $\mathrm{P}<0.05$.
\end{tabular}

In color intensity $(\mathrm{CI})$, no significant difference was found between selections, the average was 7.21 with a range of values from 5.47 to 8.51 , corresponding to selections 408 and 112 respectively.

The titratable acidity in the wines showed no differences between the selections the average value was $3.57 \mathrm{~g} / \mathrm{L} \mathrm{H}_{2} \mathrm{SO}_{4}$.

As for $\mathrm{pH}$ there were differences between the values, with the selection 112 which gave wines with lower $\mathrm{pH}$ (3.61), and the 104 and 106 selections with higher $\mathrm{pH}$ (4.05).

For alcoholic strength, there were no statistically significant differences, however the range of values was $13.5^{\circ}$ for the selection 104 to $14.6^{\circ}$ for the selections 102 and 112 .

\subsection{Sensory evaluation of wines}

En cuanto a intensidad de color la puntuación sobre la media fue para las selecciones 201, 102, 108 (Table 4).

As for color intensity the score over average were for selections 201, 102, 108 (Table 4).

As for the olfactory characters, no significant differences between wines were found for fresh fruit, whose values range from 4.40 to 5.80 for the wines of the selections 206 and 112 respectively.

For dried fruit, it had a range of values from 4.73 for the wines of selection 206, to 5.60 for the wines of the selections 112 and 401, being the average 5.23.

In aromas of fresh vegetable (pepper grass, asparagus, olives, etc.) no differences were found between wines, scores were slightly higher for selections 201, 206, 106, 104 and 408.

To dry flavors such as tea, snuff and/or spices plant no significant differences were found between wines of different selections, the values ranged from 4.27 to 6.07 for the wines of the selections 208 and 206 respectively. 
Table 4. Colour and Aromas sensory attributes of the wines of the 13 clonal selections of cv. Cabernet Sauvignon (season 20122013), Nancagua, VI region. Chile.

\begin{tabular}{cccccc}
\hline & $\begin{array}{c}\text { Intensidad } \\
\text { de color }\end{array}$ & $\begin{array}{c}\text { Fruta } \\
\text { fresca }\end{array}$ & $\begin{array}{c}\text { Fruta } \\
\text { seca }\end{array}$ & $\begin{array}{c}\text { Vegetal } \\
\text { fresco }\end{array}$ & $\begin{array}{c}\text { Vegetal } \\
\text { seco }\end{array}$ \\
\hline $\mathbf{1 0 2}$ & $6.00 \mathrm{a}$ & $5.60 \mathrm{a}$ & $5.40 \mathrm{a}$ & $4.40 \mathrm{a}$ & $4.37 \mathrm{a}$ \\
$\mathbf{1 0 4}$ & $5.13 \mathrm{a}$ & $4.73 \mathrm{a}$ & $5.13 \mathrm{a}$ & $4.47 \mathrm{a}$ & $4.34 \mathrm{a}$ \\
$\mathbf{1 0 6}$ & $5.47 \mathrm{a}$ & $4.87 \mathrm{a}$ & $5.53 \mathrm{a}$ & $5.07 \mathrm{a}$ & $4.74 \mathrm{a}$ \\
$\mathbf{1 0 8}$ & $5.80 \mathrm{a}$ & $5.60 \mathrm{a}$ & $5.00 \mathrm{a}$ & $4.53 \mathrm{a}$ & $4.33 \mathrm{a}$ \\
$\mathbf{1 1 2}$ & $5.53 \mathrm{a}$ & $5.80 \mathrm{a}$ & $5.60 \mathrm{a}$ & $4.40 \mathrm{a}$ & $4.57 \mathrm{a}$ \\
$\mathbf{2 0 1}$ & $6.07 \mathrm{a}$ & $5.00 \mathrm{a}$ & $5.27 \mathrm{a}$ & $4.53 \mathrm{a}$ & $4.50 \mathrm{a}$ \\
$\mathbf{2 0 2}$ & $5.07 \mathrm{a}$ & $5.00 \mathrm{a}$ & $5.27 \mathrm{a}$ & $4.40 \mathrm{a}$ & $4.24 \mathrm{a}$ \\
$\mathbf{2 0 6}$ & $5.53 \mathrm{a}$ & $4.40 \mathrm{a}$ & $4.73 \mathrm{a}$ & $6.07 \mathrm{a}$ & $5.37 \mathrm{a}$ \\
$\mathbf{2 0 8}$ & $5.20 \mathrm{a}$ & $5.40 \mathrm{a}$ & $5.33 \mathrm{a}$ & $4.27 \mathrm{a}$ & $4.34 \mathrm{a}$ \\
$\mathbf{3 0 1}$ & $5.33 \mathrm{a}$ & $5.20 \mathrm{a}$ & $5.07 \mathrm{a}$ & $4.47 \mathrm{a}$ & $4.74 \mathrm{a}$ \\
$\mathbf{3 0 8}$ & $5.40 \mathrm{a}$ & $5.07 \mathrm{a}$ & $4.93 \mathrm{a}$ & $5.07 \mathrm{a}$ & $4.74 \mathrm{a}$ \\
$\mathbf{4 0 1}$ & $5.53 \mathrm{a}$ & $5.27 \mathrm{a}$ & $5.60 \mathrm{a}$ & $4.67 \mathrm{a}$ & $4.34 \mathrm{a}$ \\
$\mathbf{4 0 8}$ & $5.07 \mathrm{a}$ & $5.27 \mathrm{a}$ & $5.07 \mathrm{a}$ & $4.93 \mathrm{a}$ & $4.87 \mathrm{a}$ \\
\hline Mean & 5.47 & 5.17 & 5.23 & 4.71 & 4.57 \\
\hline
\end{tabular}

Values followed by different letters are different according to the Tukey procedure of significant difference, $\mathrm{P}<0.05$.

Table 5. Mouth-feel sensory attributes of the wines of the 13 clonal selections of cv. Cabernet-Sauvignon (season 2012-2013) Nancagua, VI región. Chile.

\begin{tabular}{cccc}
\hline & Alcohol & Acidez & Astringencia \\
\cline { 2 - 4 } $\mathbf{1 0 2}$ & $5.53 \mathrm{a}$ & $5.87 \mathrm{a}$ & $5.73 \mathrm{a}$ \\
$\mathbf{1 0 4}$ & $5.80 \mathrm{a}$ & $4.60 \mathrm{a}$ & $5.20 \mathrm{a}$ \\
$\mathbf{1 0 6}$ & $5.60 \mathrm{a}$ & $5.13 \mathrm{a}$ & $5.67 \mathrm{a}$ \\
$\mathbf{1 0 8}$ & $5.80 \mathrm{a}$ & $5.73 \mathrm{a}$ & $4.93 \mathrm{a}$ \\
$\mathbf{1 1 2}$ & $5.53 \mathrm{a}$ & $5.87 \mathrm{a}$ & $5.47 \mathrm{a}$ \\
$\mathbf{2 0 1}$ & $5.00 \mathrm{a}$ & $4.87 \mathrm{a}$ & $5.33 \mathrm{a}$ \\
$\mathbf{2 0 2}$ & $5.33 \mathrm{a}$ & $5.20 \mathrm{a}$ & $4.80 \mathrm{a}$ \\
$\mathbf{2 0 6}$ & $5.53 \mathrm{a}$ & $5.20 \mathrm{a}$ & $5.07 \mathrm{a}$ \\
$\mathbf{2 0 8}$ & $5.53 \mathrm{a}$ & $5.13 \mathrm{a}$ & $4.93 \mathrm{a}$ \\
$\mathbf{3 0 1}$ & $5.67 \mathrm{a}$ & $4.87 \mathrm{a}$ & $4.40 \mathrm{a}$ \\
$\mathbf{3 0 8}$ & $5.67 \mathrm{a}$ & $5.87 \mathrm{a}$ & $5.13 \mathrm{a}$ \\
$\mathbf{4 0 1}$ & $5.73 \mathrm{a}$ & $5.73 \mathrm{a}$ & $4.80 \mathrm{a}$ \\
$\mathbf{4 0 8}$ & $5.80 \mathrm{a}$ & $4.87 \mathrm{a}$ & $4.93 \mathrm{a}$ \\
\hline Mean & 5.58 & 5.30 & 5.11 \\
\hline
\end{tabular}

Values followed by different letters are different according to the Tukey procedure of significant difference, $\mathrm{P}<0.05$.

With regard to gustative characteristics (Tables 5 and 6) alcohol, acidity, astringency and body dryness were determined. Besides the overall quality of the wines was determined (the results can be seen in Table 6).

For parameters: alcohol, acidity, astringency, body and dryness no differences between the different wines were found. In overall quality all wines achieved a high average rating.

In order to visualize more easily the differences and sensory trends in clonal selections a Principal Component Analysis (PCA) for the 13 selections Cabernet Sauvignon (Fig. 1) was performed.

The plane explains $65 \%$ of the original variability in the data (23\% dimension 1 and $42 \%$ on dimension 2 ) where dimension 1 (Dim1) separates the selections for its identification code and groups them into:

- those selections associated with the visual feature of color intensity, aromas of fresh fruit, dried fruit
Table 6. Mouth-feel sensory attributes and quality of the wines of the 13 clonal selections of cv. Cabernet-Sauvignon (season 20122013) Nancagua, VI región. Chile.

\begin{tabular}{cccc}
\hline & Alcohol & Acidez & Astringencia \\
\cline { 2 - 4 } $\mathbf{1 0 2}$ & $5.53 \mathrm{a}$ & $5.87 \mathrm{a}$ & $5.73 \mathrm{a}$ \\
$\mathbf{1 0 4}$ & $5.80 \mathrm{a}$ & $4.60 \mathrm{a}$ & $5.20 \mathrm{a}$ \\
$\mathbf{1 0 6}$ & $5.60 \mathrm{a}$ & $5.13 \mathrm{a}$ & $5.67 \mathrm{a}$ \\
$\mathbf{1 0 8}$ & $5.80 \mathrm{a}$ & $5.73 \mathrm{a}$ & $4.93 \mathrm{a}$ \\
$\mathbf{1 1 2}$ & $5.53 \mathrm{a}$ & $5.87 \mathrm{a}$ & $5.47 \mathrm{a}$ \\
$\mathbf{2 0 1}$ & $5.00 \mathrm{a}$ & $4.87 \mathrm{a}$ & $5.33 \mathrm{a}$ \\
$\mathbf{2 0 2}$ & $5.33 \mathrm{a}$ & $5.20 \mathrm{a}$ & $4.80 \mathrm{a}$ \\
$\mathbf{2 0 6}$ & $5.53 \mathrm{a}$ & $5.20 \mathrm{a}$ & $5.07 \mathrm{a}$ \\
$\mathbf{2 0 8}$ & $5.53 \mathrm{a}$ & $5.13 \mathrm{a}$ & $4.93 \mathrm{a}$ \\
$\mathbf{3 0 1}$ & $5.67 \mathrm{a}$ & $4.87 \mathrm{a}$ & $4.40 \mathrm{a}$ \\
$\mathbf{3 0 8}$ & $5.67 \mathrm{a}$ & $5.87 \mathrm{a}$ & $5.13 \mathrm{a}$ \\
$\mathbf{4 0 1}$ & $5.73 \mathrm{a}$ & $5.73 \mathrm{a}$ & $4.80 \mathrm{a}$ \\
$\mathbf{4 0 8}$ & $5.80 \mathrm{a}$ & $4.87 \mathrm{a}$ & $4.93 \mathrm{a}$ \\
\hline Mean & 5.58 & 5.30 & 5.11
\end{tabular}

Values followed by different letters are different according to the Tukey procedure of significant difference, $\mathrm{P}<0.05$.

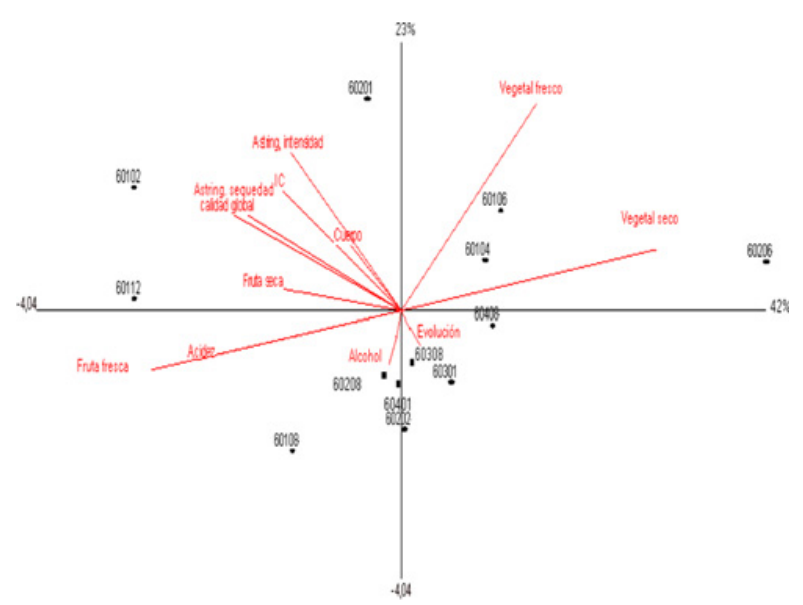

Figure 1. PCA Sensory analysis of the main components CP1 and CP2 wines of the 13 selections of cv. Cabernet Sauvignon. Season 2012-2013 Nancagua, Chile.

and structure in the mouth (astringency, body, acidity, alcohol) as are the selections 102, 112, 108 and 208.

- most notably by the intensity of aroma fresh and dry vegetable selections as 106, 104, 408, 201 and 206, the latter located in the vector of dried vegetable.

- locates in the space that shows lower intensity the attributes of the selections 308, 301, 401, 202.

\section{Conclusions}

For the 13 selections of Cabernet Sauvignon, studied and evaluated during the 2012-2013 season, it may be noted that their wines obtained by microvinification possess in their chemical composition, varietal characteristics averages to high average.

Sensorially the wines of the 13 selections have average to high averages varietal characteristics and even some excel in certain attributes, making it possible to group them according to the intensity of the attributes evaluated.

The yield (kg/plant) average was 2.6 kilos. The selection 108 , presented a production $(4.6 \mathrm{~kg} / \mathrm{plant})$ by $50 \%$ over average, which is given by larger clusters. 


\section{References}

[1] L. Muñoz, X. Moncada, P. Hinrichsen, IX Congreso Latinoamericano de Viticultura y Enología. (2003)

[2] Dirección Meteorológica de Chile. http://www. agroclima.cl (2013)

[3] SAG. Catastro vitícola nacional 2013 (2014)
[4] J. Pérez, C. Ceppi de Lecco, C. Lillo, E. Bordeu, $\mathrm{Ph}$. Pszczólkowski. IX Congreso Latinoamericano de Viticultura y Enología (2003)

[5] C. Ceppi de Lecco, Ph. Pszczólkowski, L. PérezHarvey. XIV Congreso Latinoamericano de Viticultura y Enología, Tarija, Bolivia (2013) 